MACMILLAN

MASTER

SERIES

\title{
Work Out
}

\section{Applied Mathematics}

\section{'A' Level}




\section{The titles \\ in this \\ series}

For examination at $16+$

Biology

Chemistry

Mathematics

Computer Studies

English Language

Physics

French

Principles of Accounts

Spanish

German

Statistics

For examinations at ' $A$ ' level

Applied Mathematics

Physics

Biology

Pure Mathematics

Chemistry

Statistics

English Literature

For examinations at college level

Operational Research

Mathematics for Economists 


\section{MACMILLAN MASTER SERIES}

\section{Work Out}

\section{Applied Mathematics}

\section{'A' Level}

R. Haines

and

B. Haines

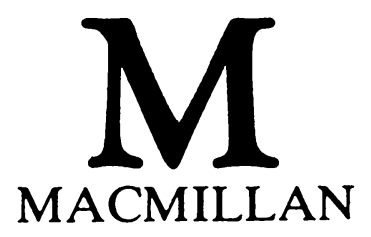


(C) R. Haines and B. Haines 1986

All rights reserved. No reproduction, copy or transmission of this publication may be made without written permission.

No paragraph of this publication may be reproduced, copied or transmitted save with written permission or in accordance with the provisions of the Copyright Act 1956 (as amended).

Any person who does any unauthorised act in relation to this publication may be liable to criminal prosecution and civil claims for damages.

First published 1986

Published by

MACMILLAN EDUCATION LTD

Houndmills, Basingstoke, Hampshire RG21 2XS and London

Companies and representatives

throughout the world

Typeset and illustrated by TecSet Ltd,

Wallington, Surrey

British Library Cataloguing in Publication Data

Haines, R.

Work out applied mathematics 'A' level.-

(Macmillan master series)

1. Mathematics - Examinations, questions, etc.

I. Title II. Haines, B.

$510^{\prime} .76 \quad$ QA43

ISBN 978-0-333-39767-1

ISBN 978-1-349-08213-1 (eBook)

DOI 10.1007/978-1-349-08213-1 


\section{Contents}

Acknowledgements

vii

Examination Boards for Advanced Level

viii

Introduction

How to Use this Book

Revision

The Examination

1 Vector Dynamics

2 Relative Motion

3 Systems of Coplanar Forces. Frameworks

4 Friction. Equilibrium of Bodies in Contact

5 Composite Centres of Mass 63

6 Constant Acceleration. Velocity-Time Graphs. Power 78

7 Projectiles

90

8 Motion in a Circle

9 Differential Equations

10 Work. Energy. Simple Harmonic Motion. Elastic Strings.

11 Impulses. Connected Particles

12 Probability

Index 
To Kevin, Sarah and Nicholas 


\section{Acknowledgements}

Over many years the questions set by the various Examination Boards have stimulated and enhanced the teaching of mathematics throughout education. Everyone involved in mathematics, both the teachers and the taught, owes a debt to the Boards for the ever-present challenge that new examination questions bring to mathematics education.

Once again our thanks go to everyone who has helped with the preparation of this book, especially to Nicholas who, with nimble fingers, processed our indifferent typing into an acceptable form.

We shall be greatly indebted to anyone notifying us of any errors.

The author and publishers wish to thank the following who have kindly given permission for the use of copyright material:

The Associated Examining Board, the Southern Universities' Joint Board, the University of London School Examinations Board and the University of Oxford Delegacy of Local Examinations for questions from past examination papers.

Every effort has been made to trace all the copyright holders but if any have been inadvertently overlooked the publishers will be pleased to make the necessary arrangement at the first opportunity.

\section{Examination Boards for Advanced level}

Syllabuses and past examination papers can be obtained from:

The Associated Examining Board (AEB)

Stag Hill House

Guildford

Surrey GU2 5XJ

University of Cambridge Local Examinations Syndicate (UCLES)

Syndicate Buildings

Hills Road

Cambridge CB1 2EU

Joint Matriculation Board (JMB)

78 Park Road

Altrincham

Cheshire WA14 5QQ

University of London School Examinations Board (L)

University of London Publications Office

52 Gordon Square London WC1E 6EE

University of Oxford Delegacy of Local Examinations (OLE)

Ewert Place

Summertown

Oxford OX2 7BZ 
Oxford and Cambridge Schools Examination Board ( $O$ \& $C)$

10 Trumpington Street

Cambridge CB2 1QB

Scottish Examination Board (SEB)

Robert Gibson \& Sons (Glasgow) Ltd

17 Fitzroy Place Glasgow G3 7SF

Southern Universities' Joint Board (SUJB)

Cotham Road

Bristol BS6 6DD

Welsh Joint Education Committee (WJEC)

245 Western Avenue

Cardiff CF5 2YX

Northern Ireland Schools Examination Council (NISEC)

Examinations Office

Beechill House

Beechill Road

Belfast BT8 4RS 